\title{
Literature Review: Stress and Mother Life Quality with Thalassemia Children Major Ages 0-18 Years
}

\author{
Inni Zakiyah, Henny Suzana Mediani, Wiwi Mardiah \\ Nursing Faculty, Padjajaran University \\ Email: zakia_iine@yahoo.co.id
}

\begin{abstract}
Thalassemia is a blod disorder which various countries pay specific attention to, both develoing and developed countries. Children with thalassemia need long-term treatment and excessive cost. It has become a burden for the family. Mother as a caregiver for thalassemia child is often confrontedby a stressful life related to the child's illness and the following treatment as well as other couses of stress; such as fear of loss, anxiety, frustration and sadness, and overwhelmed thinking of the child's recovery can affect the mother's daily activities, also the quality of life. This systematic review aimed to identify the stress and quality of life of mother with thalassemia children aged 0-18 years. Articles were collected through Google Scholar, PubMed, Proquest, Ebscho databases using the keyword Stress, Qulity of Life, Mother with Thalassemia Child including both quantitative and qualitative studies. The used articles only which were full-text, written in English, and published in 2007 until 2017. There were five articles met the criteria. The results of literature review revealed that the stress faced by the mothers especially when the children must undergo the blood transfusion for once a month. Stress was shown with psychological symptoms that can affect health. The mother's stress was assessed using the Parental Stress Scale (PSS), and for the quality of life measured by HRQOL SF-12v2, with Likert scale, the lowest score 0 and the highest 100. Found that if the mother' quality of life also decreased. Conclusion: mothers with thalassemia children then to experience stress, resulting in both physical and psychological impact on the mothers' health, thus affecting the quality of life. By this literature review, expected that will be more research related to stress and quality of life of mothers with thalassemia children, thus reducing stress on mothers that affect the quality of life.
\end{abstract}

Keywords : Mother with thalassemia child, quality of life, stress. 
Inni Zakiyah: Literature Review: Stress and Mother Life Quality with Thalassemia Children

\section{Introduction}

Major Thalassemia is the genetic disease. This disability can cause abnormal development of red blood cells and at last causing anemia. Thalassemia is also common interference found in the world, by happening of dominant in the countries both Mediterranean and Southeast Asia. About, estimated 240 million people as carrier $\beta$-thalassemia in the world, while 100,000 children with major thalassemia born every year. In Iran, the prevalence of thalassemia at about $3-4 \%$ of the common population and there are over three million of carriers of $\beta$-thalassemia. Nearly 26.000 patients with major thalassemia and 800 babies with thalassemia born every year in Iran, (Pauraboli et al., 2017).

Children of thalassemia require blood transfusion each months, chelation therapy of iron regularly and in various cases, transplantation of bone marrow may happen. Likewise, the parent of thalassemia's child appears the impact on emotional suffers to generation repeatedly. They consider themselves the responsibility, feel mistake, hopeless and worry about health and the future of affected children, (Gyan \& Mudra, 2012).

Children of life with major of $\beta$-thalassemia need medication for life, causing social burden and finance of large on patient, family and system of health treatment. Thalassemia raises unusual impact on life of children; patient become anaemia and the activity is disturbed effect of fatigue until physic become tired and cannot be tolerant to them. Overstimulation of bone marrow led to children to create the changing a feature of craniofacial them and delayed growth, the network of osteoporotic, ascites and enlargement of the liver and at last arrythmia and death produced by heart failure, (Pauraboli et al., 2017).

Thalassemia can affect life in children, such as this condition, the approach of family vigilance along life child. Globally, 15 million people estimated suffer from thalassemia. In India, 10,000 children born with thalassemia every year, and the child born through thalassemia. In India, the carrier level for $\beta$-Talasemia varies from $1-17 \%$ with average $3.2 \%$ which means that one of 25 people in India is thalassemia carrier. One of 204 children born on a year suffer thalassemia, (Indian Organization of Thalessemia, 2014).

Thalassemia also causes the child often must be in hopitalization because medication's process is running perpetually. It becomes pressure for family's member which appears emotional, worry, fear, difficulty in tackling of feel, and the following effect on family will be problem with the child of thalassemia sufferer. Therefore, the child's family of thalassemia will often execute the visiting to the hospital, causing a psychosocial burden to the family. Research has pointed that parent who tackles and adapts to chronic disease from child tend has the over negative attitude and fatalistic toward child disease, (Saldanha, 2015).

The most child is maintained in the hospital, with medication needs the extra attention by family's member as caretakers who support the process of treatment. The chronic disease and disability have the significant impact on caretaker and family member (Hussain \& Juyal, 2007; Shanmugam \& Ramachandra, 2015).

The thalassemia incident can affect the psychological status of parents who cause afraid, hopeless and powerless. The psychological support to caretaker is essential and the main of comprehensive medical treatment. On a month, nearly 100 patients experience thalassemia by visiting hospital St. John to make blood transfusion routinely. Unvalued of burden on parent related to condition of child disease. It becomes the consideration for a researcher, which this sense of the strong necessity learns how to solve parents stress of children by thalassemia in undergoing the process of child treatment (Saldanha, 2015).

A sectional cross-study executed by National Institute of Mental Health dan Neuroscience, Bangalore on 44 nurses to evaluate the contribution of psychiatrist issue and concern about disease toward life quality of caretakers point that pyschiatrist issue and concern about caretakers related to thalassemia contribute with the disruption of his quality life (Saldanha, 2015).

Mother usually takes the active role of their children treatment is sick and even it may stop working and their favourite activity. Likewise, they assume a larger pressure than 
Inni Zakiyah: Literature Review: Stress and Mother Life Quality with Thalassemia Children

father and stay on depression risk is higher.

\section{Research Method}

The purpose of observation this literature review is to identify stress and quality life mother with child thalassemia in ages 0-18 years. This article gathered by data baseGoogle Scholar, PubMed, Proquest dan Ebscho with using the keyword of stress, life quality, mother with thalassemia child, consist of quantitative and qualitative of study. The article used just article by complete text, written in English, published from 2007 to 2017. Discovered 5 articles that fulfil criteria. The methodology quality valued using the guide Critical Appraisal Skill Programme and guide PRISMA is found 48 articles and just 5 articles that fulfill criteria.

The assessment diagram of PRISMA to determine literature is:

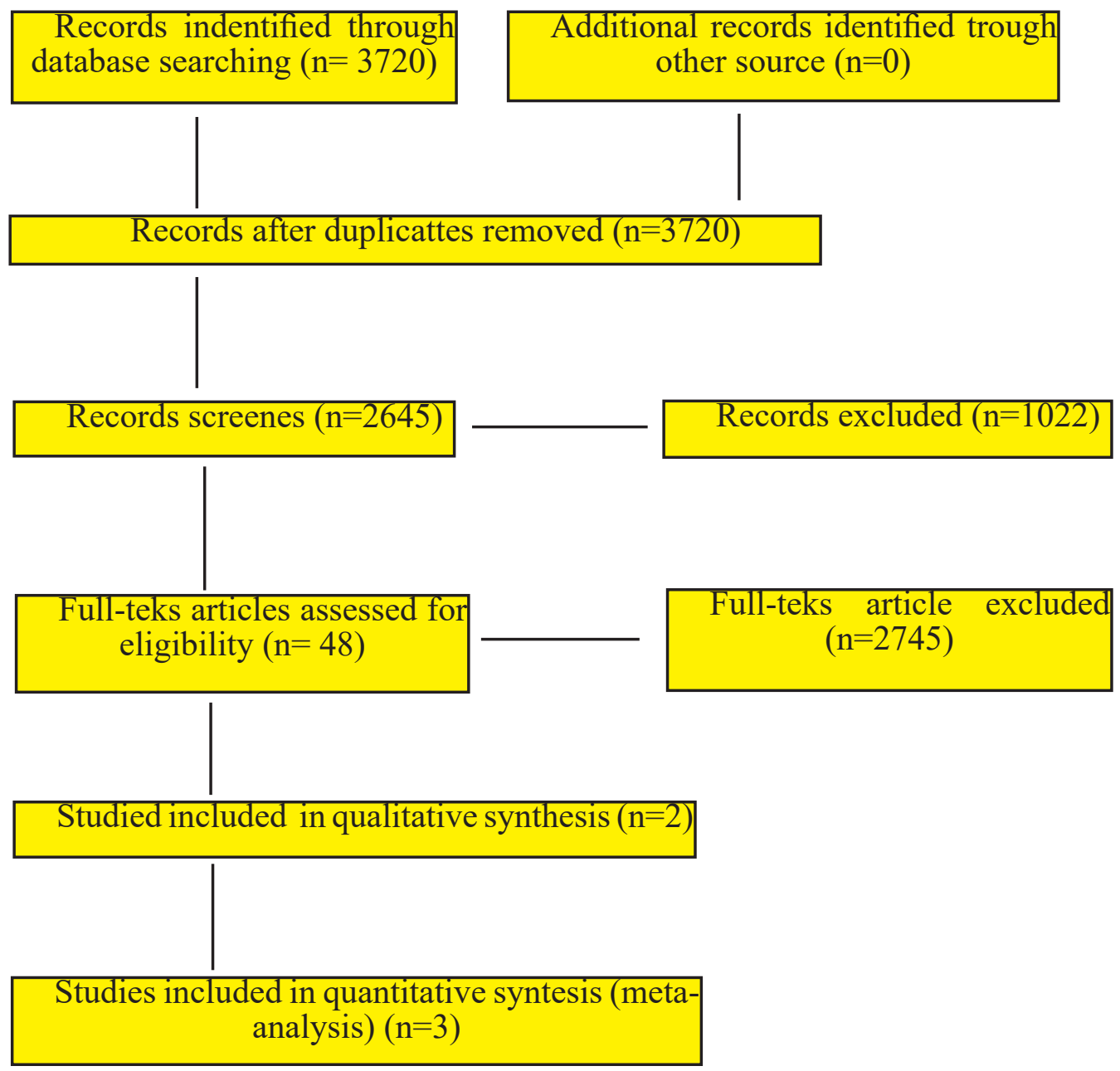




\section{Research Results}

Result of search by database is discovered 48 articles, just 5 articles that fulfil criteria and specifically stress relationship and causality of life child with child of thalassemia. The chronic disease on child has impact including physic, psychology, social, spiritual, culture and economy, does not just to child but parent too. Parent have the essential role to help child is chronic sick adapte with his disease to reach optimal growth. The issue often faced is several parents still stress in maintain, facing and accepting the reality that their child has disease that threat soul to require specific attention from parent especially, mother, also needs medication perpetually and requires cost is not much such as thalassemia.

This following is characteristic table of article that fulfil inclusion criteria:

\begin{tabular}{|c|c|c|c|}
\hline $\begin{array}{c}\text { Autors/Years/Place of } \\
\text { Studi } \\
\end{array}$ & Title & Participant & Results \\
\hline $\begin{array}{l}\text { Sandra J. Saldanha/ } \\
\text { 2015/St. Jphn's } \\
\text { Medical College } \\
\text { Hospital (SJMCH), } \\
\text { Bangalore. }\end{array}$ & $\begin{array}{l}\text { Stress and Coping } \\
\text { among Parents of } \\
\text { Children Having } \\
\text { Thalassemia }\end{array}$ & $\begin{array}{l}\text { Parent of } \\
\text { Children } \\
\text { Thalassemia }\end{array}$ & $\begin{array}{l}\text { The data presented in table } 1 \text { show that } \\
82 \% \text { elicited financial stress, } 59.60 \% \text { had } \\
\text { emotional stress, } 48.60 \% \text { experienced } \\
\text { social stress and } 43.75 \% \text { had physical } \\
\text { stress. The findings reveal that there is a } \\
\text { significant correlation }(\mathrm{r}=-0.41) \text { between } \\
\text { the stress score and problem oriented coping } \\
\text { at }<0.001 \text { level. This indicates that the } \\
\text { parents using less problem oriented coping } \\
\text { mechanisms are experiencing more stress. }\end{array}$ \\
\hline $\begin{array}{l}\text { Prasomsuk et } \\
\text { al./2007Thailand }\end{array}$ & $\begin{array}{l}\text { Lived Experiences } \\
\text { of Mother Caring } \\
\text { for Children With } \\
\text { Thalassemia Major } \\
\text { in Thailand }\end{array}$ & $\begin{array}{l}\text { Mother with } \\
\text { Thalassemia } \\
\text { Children }\end{array}$ & $\begin{array}{l}\text { Analysis identified six core themes that the } \\
\text { mothersencountered with their thalassemic } \\
\text { children. All participants agreed that Hb } \\
\text { E } \beta \text {-thalassemia major affected their lives } \\
\text { significantly. The six themes identified } \\
\text { were lack of knowledge about thalassemia, } \\
\text { psychosocial problems that the mothers } \\
\text { experienced, financial difficulties faced by } \\
\text { the mothers, concerns for the future, social } \\
\text { support systems, and the effectiveness of } \\
\text { healthcare services. }\end{array}$ \\
\hline $\begin{array}{l}\text { Pauraboli et } \\
\text { al./2017Iran }\end{array}$ & $\begin{array}{l}\text { The Burden of } \\
\text { Care: Experiences } \\
\text { of Parents of } \\
\text { Children With } \\
\text { Thalassemia }\end{array}$ & $\begin{array}{l}\text { Parent with } \\
\text { Thalassemia } \\
\text { Children }\end{array}$ & $\begin{array}{l}\text { According to data analysis, the main } \\
\text { theme was "Parents Burden of care" was } \\
\text { emerged. Through this theme, we created } \\
\text { the following categories: 1-immersion } \\
\text { in suffering, 2- stigma and social death, } \\
\text { 3- uncertainty about future 4- absence of } \\
\text { a support network. Results of this study } \\
\text { showed that some parents manage their } \\
\text { problems alone. Also, deep cognition of } \\
\text { parents' needs was obtained considering the } \\
\text { experiences of parents. Thus, it is necessary } \\
\text { that health provider provides support and } \\
\text { education by appropriate planning. Nurses } \\
\text { are recommended to help these parents by } \\
\text { appropriate interventions. Training life skills } \\
\text { to them can be very helpful in reducing } \\
\text { the severe difficulties imposed on these } \\
\text { parents in Iran. Furthermore, it is helpful } \\
\text { to determine the parents' burden of care to } \\
\text { improve the family function. }\end{array}$ \\
\hline
\end{tabular}


Inni Zakiyah: Literature Review: Stress and Mother Life Quality with Thalassemia Children

\begin{tabular}{|c|c|c|c|}
\hline $\begin{array}{l}\text { Hazlina M. M, } \\
\text { Rumaya J, Siti Nor } \\
\text { Y/2017Malaysia }\end{array}$ & $\begin{array}{l}\text { Mediating Role } \\
\text { of Perceived } \\
\text { Social Support on } \\
\text { the Relationship } \\
\text { Between Stress } \\
\text { and Quality of Life } \\
\text { Among Mothers } \\
\text { With Thalassemia } \\
\text { Children in } \\
\text { Malaysia }\end{array}$ & $\begin{array}{l}\text { Mother with } \\
\text { Children } \\
\text { Thalassemia }\end{array}$ & $\begin{array}{l}\text { Findings indicated significant negative } \\
\text { direction in relationships between stress } \\
\text { and social support and between stress and } \\
\text { quality of life. Besides that, the relationship } \\
\text { between social support and quality of } \\
\text { life showed significant positive direction. } \\
\text { Results also showed that when controlling } \\
\text { for the mediating variable, stress has the } \\
\text { strongest significant influence on quality of } \\
\text { life }(\beta=-8.292, p<0.001) \text { and confirmed } \\
\text { that social support is significantly mediating } \\
\text { that relationship. }\end{array}$ \\
\hline $\begin{array}{l}\text { Valliammal } \\
\text { Shanmugam, } \\
\text { Ramachandra/2015/ } \\
\text { Bangalore }\end{array}$ & $\begin{array}{l}\text { Stress Factors } \\
\text { among Caregivers } \\
\text { of Children with } \\
\text { Thalassemia }\end{array}$ & $\begin{array}{l}\text { Caregivers with } \\
\text { Thalassemia } \\
\text { Children }\end{array}$ & $\begin{array}{l}\text { Results showed that caregivers experienced } \\
\text { significant stress on the following domains: } \\
\text { daily care stress (DM1) with a score of } 2.82 \\
+1.14 \text { (mean } \pm \text { sd), family emotional stress } \\
(\mathrm{DM} 2) 24.43 \pm 9.65 \text {, social stress }(\mathrm{DM} 3) \\
3.30 \pm 1.59 \text {, financial stress (DM4) } 0.90 \pm 0.30 \\
\text { and personal development stress (DM5) } \\
3.77 \pm 1.73 \text {. Results indicated a significant } \\
\text { positive correlation between the stress } \\
\text { domains and age, }(\mathrm{r}=0.64, \mathrm{p}<0.05) \text { family } \\
\text { size }(\mathrm{r}=0.58, \mathrm{p}<0.05) \text { and duration of contact } \\
(\mathrm{r}=0.70, \mathrm{p}<0.05) \text { of the caregiver with the } \\
\text { child. }\end{array}$ \\
\hline
\end{tabular}

\section{Discussion}

Based on a result of literature review from several articles is discovered several actors influences stress and life quality with children thalassemia among others:

\section{Deficient of mother knowledge about Thalassemia}

Even though the nurse has given information to mother about thallasemia, they mostly show less knowledge about thallasemia and his complication. They did not know and cannot access information about major thallasemia in prevelance and his control. Mother also deficient recognize that thalassemia descended from his and mother late execute diagnosis test of prenetal after knowing children was diagnosed to have thalassemia. It is supported by research is conducted by Saldana (2015) and Prasomsuk et al. (2017).

Based on qualitative research is conducted by Prasomsuk et al. (2007), identifying of the gist six themes is faced mothers with child thalassemia. All participants deal that $\mathrm{Hb}$ E-thalassemia of major affects their life significantly. The six themes are identified is less knowledge about thalassemia, psychosocial issue experienced by mother, difficult of finance is faced by mother, concern about future, the system of social support, and effectivity of health services.

Based on the research above Saldanha (2015), state that positive attitude toward stress is appearing but necessary is tackled well. It can be executed by giving psychologist support; the further information about the condition of disease, screening and has counselling session to help them in dealing children disease positively. The researcher suggests that all parents of children who suffer thalassemia should be given the counselling and supporting of psychologist adequate to solve disease more effective.

\section{Psychology Issue}

The parent suffers psychology tension because difficulty cares for child thalassemia. They state that they are pressured and they see their children is sad. They state apprehension toward the child born by thalassemia. Next, the parent tells their experience accepting thalassemia diagnosis abruptly, causing decision, sad and they did not believe their child disease. It is supported by qualitative research is conducted by Pouraboli et al. (2017) stated that a father of two children 
Inni Zakiyah: Literature Review: Stress and Mother Life Quality with Thalassemia Children

of thalassemia states: "When we are known about disease our children, we are hopeless and hopeless. Our life becomes bitter. "The next reaction of the parent is rejection; did not believe in diagnosis causes they change medic team or hospital. A father lives in a village near Jiroft (a city in South Kerman), states: "after accepting the result of test from Dr F give knowing us about our children was diagnosed with thalassemia. We go to Jiroft to confirm his result by another doctor. We cannot believe his too; therefore, we go to Kerman.

Parent believes that thallasemia diagnosis to their children impacts on mental status and their emotional, family relationship, love and affection amongst the couple. Concern about the born of a child thalassemia, several mothers undergo the operation of tubal ligation is caused separation and divorce in a number of families. One of a father states; " we like to have at least four childs. By happening thalassemia, we do not want to have child again. This issue annoys us and the family appears. It is not the previous woman that I love this child disappears". Pouraboli et al. (2017).

Based on the discovery above, qualitative research Prasomsuk et al. (2017), also states that mostly mother concerns about the possibility their children may need splenectomy in the future. They want to know whether the children will be healthy and grow as high as others children after the operation. A mother tells her feels about this problem.

I feel afraid of all this. I wonder why he increasingly often very tries his blood now. Last month, I asked to doctor whether or not they will give the operation. He tells that it does not conduct now. He asks whether I will accept the reality of operation will not make everything well at all. Besides, the operation is painful. My nephew lives near here undergo the previous operation, besides that, he is sick easier. Two or three months past, he even cannot undergo in spite he has undergone the operation (Prasomsuk et al., 2017).

\section{Economic Burden (Difficulty of finance) consequence the treatment process}

The children live with major of $\beta$-thalassemia requires the medication for life of regular blood transfusion and iron chelation therapy, cause social burden and finance is large on patient, family and system of health treatment. Parents often are burdened with treatment cost on child thalassemia is conducted perpetually. It is supported by research is conducted by Saldanha (2015) in her research data points that $82 \%$ respondents experience stress cause the finance on the treatment process their children are running perpetually.

It can be seen from income section of respondents are discovered the product that most of them namely, $63 \%$ of parents are the worker of semi-skilled, $19 \%$ of them is competent and $18 \%$ of them are not the competent labour. $65 \%$ of them have monthly income between Rs.1,001-5,000; $18 \%$ of them Rs.5,001-10,000; 7\% between Rs.10,001-15,000 and Rs. 15,001-20,000 respectively and $3 \%$ of them have income at up Rs.20.000 (Saldanha, 2015).

Based on the discovery above, the result of research Shanmugam and Ramachandra (2015), also state that caretakers experience the significant stress on the following domain: stress of daily treatment (DMI) with score of $2,82+1,14$ (average $\pm \mathrm{sd}$ ), tension of finance (DM4) $0,90 \pm 0.30$, concludes that stress happens significantly amongst of caretakers is stress domain "emotional stress of family", points that family member experiences much more burden give the treatment and need the extra cost to children of thalassemia.

From data above, it can be seen that the respondent income very limited to be the medication of thalassemia child is conducted all life perpetually. It becomes the burden to parent in the financing of child for undergoing the treatment process.

The Social Support

The treatment of lifetime of thalassemia patient will often cause the hospitalization especially when they have other the health complications. This hospitalization often gives the psychology impact on their parent because they always think about condition their child disease and may not solve because the limited access to obtain support and the accurate information. Therefore, all of this sources will contribute to stressor toward mother and influence their life quality as 
Inni Zakiyah: Literature Review: Stress and Mother Life Quality with Thalassemia Children

entire (Hazlina et al., 2017).

Based on above, the result of research cross-sectional is conducted by Hazlina et al. (2017). Involves 372 mothers with child thalassemia conducts the medication of blood transfusion routinely every month, from ten Government hospitals in Malaysia. Data collection consisted of the face-toface interview use Parental Stress Scale, Multidimensional Scale of Social Support Perceived and SF $12 \mathrm{v} 2$ measure variable respectively, which have been agreed by Medical Ethics Research Committee (MREC). To social support measured by using Multidimensional Scale of Social Support Perceived (MSPSS). Social support is accepted from three sources: 1) the friends ' I can talk about my issue with my friends, 2) Family; My family really try to help me' and 3 ) other significant 'I have the special person is the consolation source of the real to me'. Every item is measured on the Likert scale in seven points starting from 1 (strongly agree) to 7 (strongly disagree).

Total measure of adequacy for social support which is perceived by score average on 12-items, with the higher score shows social support which is perceived larger. The total scale had been proven have the consistency of the internal of realibility 0.88 (Cronbach's alpha) and reliability of repetition test 0.85 and show the internal consistency is high with alpha Cronbach 0.93 to the other peoples significantly, 0.88 to family and 0.96 to friends (Zimet et al., 1988). MSPPS is translated into Melayu language and have been validated in previous research $(\mathrm{Ng}$ et al., 2010). In this research, the instrument shows good validity on Family Division Cronbach Alpha is 0.77, Alpha Cronbach to friend's part is 0.89 and the other significant values are 0.95. The entire item shows Cronbach Alpha as high at 0.88 and this value very close with 0,9 shows the good value (Hazlina et al., 2017).

The finding shows the significant negative direction in the relationship between stress and social support, as well as between stress and life quality. Besides, the relationship between social support and life quality show the significant positive direction. As result of stress have the significant influence are most strength toward life quality $(\beta=-8.292, \mathrm{p}$ $<0.001$ ), it means the importance of social support which is perceived by mother in sustaining the stress effect on their quality life (Hazlina et al., 2017).

\section{Conclusion}

The analyze of five articles have been reviewed concluding there is discovery from all of the researchers show in caring for children with thalassemia have the significant impact toward the parent life as caregiver. The impact appears in this literature caused by several factors namely less the mother knowledge about thalassemia disease, the mother psychology issue is disturbed effect the children treatment and her medication, its cost large needed the parent family in the children treatment, less the social support toward mother in caring thalassemia child.

The factors above cause appear the stress on parents until the mother of life quality becomes bad along the child of treatment process with thalassemia result of pressure is experienced mother. This research may useful in the increasing information about thalassemia and increase realizing of nurse and other healths.

\section{References}

Hazlina M.M., \& Rumaya J.S.N.Y. (2017). Mediating role of perceived social support on the relationship between stress and quality of life among mothers with thalassemia children in malaysia. International Journal of Public Health and Clinical Sciences, 4(1), 103-123.

Pouraboli, B., Abedi, H.A., Abbaszadeh, A., \& Kazemi, M. (2017). The burden of care: Experiences of parents of children with thalassemia. Journal of Nursing \& Care, 6(2). https://doi.org/10.4172/2167-1168.1000389.

Prasomsuk, S., Jetsrisuparp, A., Ratanasiri, T., \& Ratanasiri, A. (2007). With thalassemia major in Thailand, 12(1).

Saldanha, S.J. (2015). Stress and coping 
Inni Zakiyah: Literature Review: Stress and Mother Life Quality with Thalassemia Children

among parents of children having thalassemia, 4(7), 849-853.

Shanmugam, V., \& Ramachandra. (2015).
Stress factors among caregivers of children with Thalassemia. Manipal Journal of Nursing and Health Sciences, 1(1), 39-42. 